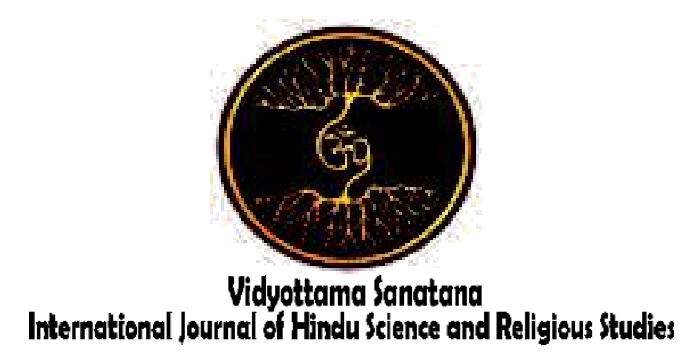

Vol. 3 No. 2 October 2019

\title{
FORMATTING OF RELIGIOUS ATTITUDE OF HINDU BALI YOUTH IN THE CONTEXT OF RELIGION CONVERSION (Ethnopedagogy Study in Taro Tegalalang Village, Gianyar)
}

\author{
By: \\ Ni Putu Suwardani, Wayan Paramartha, Ni Made Indiani. \\ Hindu Indonesia University \\ E-mail : niputusuwardani@gmail.com,paramartha1960@gmail.com, \\ indianimade@gmail.com
}

Received: August 22, $2019 \quad$ Accepted: September 25, $2019 \quad$ Published: October 31, 2019

\begin{abstract}
Nowdays, coversion of religion is popular issue to discuss especially for Hindus in Bali as well as outside Bali. This paper conveys some alternatives of how to stay in our religion namely Hindu. There fore the purpose of this study, to analyze: (1) Reasons for the importance of the formation of religious attitudes of Hindu youth in Taro Village; (2) Strategies for the formation of religious attitudes of Hindu youth in Taro Village; and (3) Implications for the formation of Hindu teenage religious attitudes towards religious knowledge, religious beliefs, and religious behavior. Theories used as scalpel are: phenomenological theory, constructivist theory, and eclectic theory of behavior. This research is classified as a qualitative research, with a multiperspective approach namely theological, phenomenological, psychological and ethnopedagogical. Data collection techniques with unstructured interviews, non-participation, observation, and study of documents. Data were analyzed using qualitative descriptive techniques, the Miles and Hubeman cycle analysis models. Conclusions: (1) Reasons for the importance of forming religious attitudes of Hindu youth in Taro Village: increasing religious knowledge, suppressing religious fanaticism, forming religious tolerance, and making children morally noble; (2) Strategies for the formation of religious attitudes of Hindu youth in Taro Village, by: providing examples and modelling through a persuasive approach, by creating a religious atmosphere, by internalizing religious values, by habituation, and cooperation with partners. (3) Implications for the formation of religious attitudes: implications for increasing understanding of religion, strengthening of faith / belief (sraddha and bhakti) in religion, and religious behavior becoming more mature, religion becoming an attitude of life.
\end{abstract}

Keywords: Formation, Religious Attitudes, Ethnopedagogy. 


\section{INTRODUCTION}

In recent years community awareness of the importance of inculcating religious values in children has begun to increase. Religious education has an influence on the formation of one's religious attitude. The size of the influence is highly dependent on factors that can motivate someone to understand religious values (Mujiati \& Triyanto, 2017: 69). Parents have a very important role for children's religious education in the family. This is in line with the view of Jalaluddin (1996: 68) that the introduction of religious teachings from an early age is very influential in shaping religious awareness and experience in children. The existence of religious awareness and experience in children will shape their religious attitude.

Religious attitude is the manifestation of human potential as religious beings. As Eliade stated, that human nature is a religious creature (homo religious) (Sastrapratedja (ed.), 1982: 37). The hallmark of homo religious is the type of people who do not merely live in the real nature which is natural (profane), but they also live in a sacred realm that is full of religious values reflected in their attitudes. Religion in human life functions as a value system that contains certain norms that will become a frame of reference in behaving and behaving to be in line with the religious beliefs that it adopts. (Jalaluddin, 2008).

The phenomenon on the ground, that people claim to be religious but the religious attitude that is shown is not in accordance with the "spirit / soul" of the religion itself. Someone claims to be a follower of a certain religion, but his attitude and behavior are not in accordance with the goals of the religion itself. Many people "wear religious clothes", but the contents are not religious; it means that people claim to be religious, but do not carry out their obligations as people of religion. They are formally religiously at the surface level only. The practice of religion is carried out without appreciation and meaning. Religion is seen as limited to complete one's identity (labeling) not as a need, and as a "social necessity". Such religion is less able to contribute to the formation of a truly religious attitude.

On the other hand it is also easy to find people who behave in an inclusive religion, fighting for their religion to be the best and the most correct, when in fact they themselves lack understanding of the teachings of their own religion. This attitude often leads to religious conflicts, both internal (for those who are too fanatical about their religion), or externally.

Lack of knowledge and understanding of religion also allows the conversion of religion, which is converting from the original religion to another religion (Jalaluddin, 1996: 178). Intrinsic conversion of religion occurs because of an inability to understand the teachings of his religion, and a lack of confidence in the religion that is followed. Whereas extrinsically it can occur because the offer is more profitable worldly than other religious parties. For those who have a high religious attitude, they will not easily accept the offer despite the difficult circumstances of life.

In addition, the experience factor has an important role in the formation of one's religious attitude because the emergence of a religious attitude on someone is when the individual knows something or an object, both the object in internal and external form. If the child has experiences that contain many religious values during their childhood , then they will have their personality in good qualities (daiwi sampad). Conversely, if his childhood experience is far from religious teachings, then the elements of personality will be far from religion, which makes the child's personality unstable and easily influenced by an uneducating environment. As Freud stated, the early period was the formation of the foundations of attitudes, habits, personality, and behavior. If the basics of attitudes, habits, personality, and behavior have been formed in the early days properly, it will facilitate the development for future periods (Santrock, 2004: 36). Thus, the inculcation of religious values in order to form religious 
attitudes is important to be done early on through various religious activities. The question is how the cultivation of religious values is carried out in shaping the religious attitudes of Hindu teenagers in Taro village, it is important to study it from an ethnopedagogical point of view amid the concerns of the Hindus of the Taro village of religious conversion, namely from Hinduism to Christianity which has settled for a long time in Taro Village.

\section{METHODS}

This research is a type of qualitative research because the findings are not obtained through statistical procedures or other calculations and more requires a series of words, not numbers (Bogdan \& Taylor, 1992: 67). Qualitative research essentially uses a natural setting, with the intention of interpreting phenomena that occur and is carried out by involving various existing methods (Williams in Moleong, 2014: 37). Qualitative researchers also try to understand symptoms as respondents understand (Poerwandari, 2005: 63), and tend to have opportunities to build relationships with research subjects, so they can see the world from the subject's point of view (Strauss \& Corbin, 2015).

The approach used in this research is a multiperspective approach namely phenomenological, psychological and ethnopedagogical to reveal the strengthening of the Hindu young people's religious attitudes in the Pakraman Taro Village, Tegalalang Gianyar, based on local knowledge or local wisdom and social aspects as a source of innovation and skills that can be empowered to strengthen religious attitudes. The subjects in this study were the Hindu young generation of Taro Village, who were selected randomly, the instructors and coaches of pasraman, the parents, the Bendesa Adat and community leaders. The reason for choosing those subjects, because they were as the actors of strengthening the religious attitudes of the younger generation of Hindus and they were considered to provide information on the topic of study.

Data was collected by using in-depth interview techniques (semi-structured interviews) and assisted with recording devices, non-participation observations and document studies. These three techniques are commonly used in qualitative research (Sukmadinata, 2013: 34). In this study the researchers themselves as key instruments. In order to obtain credible data, it is recorded as accurately as possible, fully and neatly documented the data collected, and rechecking the data with researcher triangulation and method triangulation. Data analysis is carried out through data organization steps, coding and analysis, testing of allegations, and interpretation stages. Reporting is descriptive narrative.

\section{RESULTS AND DISCUSSION}

\section{Religious Attitudes}

Generally, attitude is an assessment of an object namely cognitive, affective, and conative. According to Maio and Haddock attitude is a comprehensive evaluation of an object based on cognitive, affective, and behavioral information (Marcher \& Clayton, 2012: 3). The above understanding shows that attitude is an activity that expresses a person's feelings towards an object. The activity will eventually cause a reaction and response of the object so that it will cause likes or dislikes.

According to the Big Indonesian Dictionary (2008: 720) the word religious means to be religious, or which has to do with religion. Basically religious is something that is related to religion. The word religious in the context of education can be interpreted as an effort to create a religious atmosphere so that in carrying out activities it is still based on the religion adhered to.

Religiousity is an attitude and behavior that is obedient in carrying out the teachings it adheres to, tolerant of the implementation of worship of other religions, and living in harmony with followers of other religions. Religious is a form of human relations with 
its creators through religious teachings that have been internalized in a person and reflected in their daily attitudes and behavior (Thontowi, 2005: 63). Someone who has a high religious attitude will be seen from his daily behavior. Likewise with people who pay less attention to their religion, this will be seen in their actions.

\section{The Importance of Shaping Religious Attitudes of Hindu Bali Youth in Taro Village}

The formation of religious attitudes towards Hindu teenagers in Taro Village certainly starts from the family environment as the foundation of the main values of religious education, and the educators are their parents. Parents are natural educators, so they have the responsibility to care for / nurture, raise, supervise, protect, foster and guide their offspring. Education in the family is also a basic education for the formation of the child's religious soul in this case the child's religious attitude.

The Hindu community in Taro village realizes how important are religious attitudes formed, especially among young people, namely adolescents, because adolescence is a very unstable age and very susceptible to influence. The Hindu community of Taro Village is very intense in forming children's religious attitudes, because there are Kahyangan Jagat Temple, Gunung Raung Temple in Pakraman Taro Village, which often has religious ceremonial activities. Taro Village is also a tourist destination with the "White Ox" as a mascot and also its natural view visited by many tourists. Some Christians have been in Taro Village especially in Pakuseba, where there has been a conversion of religion from Hinduism to Christianity. The tourists not only bring different cultures, but may be contrary to the values and traditions as local wisdom of the Taro Village. Therefore, data collected from doing depth interviews and observations found that information on the importance of children's religious attitudes is formed, as follows:
First, to increase the religious knowledge of the Hindu youth in Taro Village. Parents realize that one of their tasks is to instill religious values in children. By instilling these religious values children are expected to have a strong knowledge of their religion (interview with Ketut Bdrt., 03.03.19). The family as the first and foremost social institution, has the most strategic meaning in filling, equipping, and providing knowledge and inculcation of religious and religious values to children. Gilbert Highest (in Jalaluddin, 2008: 291) states that the habits and knowledge possessed by children are mostly obtained from family education. Of course the understanding of religion provided is adjusted to the development and maturity of children's religion. Without a good understanding of religious teachings and values, the beliefs about their own religion are not strong either. This not only has an impact on the religious attitudes and behaviors concerned, but they will also easily convert their religion from the original belief (religion) to Hinduism to another faith (religion). Therefore, understanding religion and Hindu teachings becomes important for Hindu youth in growing their souls and religious attitudes.

Second, suppress religious fanaticism. Religious fanaticism is an understanding that shows the belief and love of religious teachings strongly, sometimes even excessive. A strong belief is not wrong, but in reality that belief can turn unhealthy when people begin to believe that people outside their religious group are enemies. Psychologically, someone who is fanatical is usually not able to understand anything that is outside of himself, to the problems of other people or groups, clear signs of fanaticism are the inability to understand the individual characteristics of others who are outside the group. Loyalty of the people towards the religion they hold tends to give birth to an exclusive ideology that can give rise to tensions against other groups (Smith, 1995: 5), and drive religious conflicts, even religious conversion. According to Liliweri 
(2013: 117), one of the triggers for conflict among and internal religious communities is because certain religious communities or religious groups cannot understand correctly about religious communities or other religious groups, who have different idiological backgrounds, where things it affects the way of thinking, behaving, and acting differently from himself. Because of this lack of understanding, many religious communities do not know how to live in a pluralistic, multi-religious, multi-ethnic and multicultural society. Recognizing the existence of religious fanaticism in the community, it is important to establish the religious attitude of Hindu adolescents in the village of Taro so that Hindu youth can respect other people.

Third, form an attitude of tolerance with followers of other religions. Tolerance is an attitude of mutual understanding and mutual acceptance of one another against everything that is different from it. This tolerance is always maintained by Hindus in Taro Village by forming the religious attitudes of adolescents, so that they can respect to each other, including Christians in Taro Village (Ni Nyoman Sy., 27.04.19). Hindus and Christians living in one village are expected to always live in harmony and respect for one another. The life of paras-paros, sagilicsaguluk, salulung sabayantaka seems to be cultivated in the village of Taro. They assume that they have been siblings for a long time as in the concept of "Vasudewa Kutumbhakam". Because after all the attitude of tolerance and the teachings of compassion towards each other exist in every religion, and that will be realized when people have a religious attitude. Likewise the doctrine of humility that can be developed into human readiness to respect others (Muhaimin, 2012: 246).

Fourth, to make children noble. Morals or character is the only very fundamental aspect of life. The purpose of instilling moral values (character) is that children are accustomed to doing good, beautiful, noble, praiseworthy, and avoiding bad, ugly, despicable, despicable, and maintained harmonious relationships with God, fellow humans, and the environment (Umary in Thoha, 1999: 135). These qualities are also desirable to occur in Hindu youth in the village of Taro, and do not behave in a contrary to the values of the Hindu religion that are inculcated (interviews with I Made Sj., And Wayan Nrt., 03.03.19). The purpose of moral education, is that people are on the truth and always on the right path, the path that has been outlined in religious teachings. Therefore, the formation of religious attitudes carried out by the Hindu community in Taro village, Tegalalang Gianyar, with the intention that children have good character in mind (manacika), which is manifested in actions (kayika), words ( wacika), attitudes, feelings, and personality.

\section{Strategies in Shapping Religious Attitudes on Hindu Bali Youth in Taro Villag}

The formation of religious attitudes does not happen by itself, but is due to external or environmental influences. Humans are not born with complete attitudes, but the attitudes are born and develop together with the experience gained. The strategies for forming Hindu religious attitudes of young people in Taro Village include:

First, by giving examples or providing models through a persuasive approach. Parents in Taro Village always try to give examples of religious behavior such as observing worship, praying, behaving politely, respecting others, and so on. In this way the child's religious attitude gradually forms (Made Sp., Interview 03.03.19). Children who as children did not know anything about matters related to religious life, never went with parents to places of worship, listened to religious lectures, and so on, then even after they grew up they did not even pay attention to religious life (Hasbullah, 1999: 32). The child's attitude is basically imitative or imitating, so the example of parents and those around them makes a big contribution in instilling, 
growing, and developing their religious attitude.

Second, by creating religious atmosphere. Creating a religious atmosphere, is to create the entire atmosphere of the environment with religious values and behavior (Jalaluddin, 2008: 88). The strategy of forming the religious attitudes of Hindu teenagers in the Taro is done by familiarizing family members with praying before traveling, providing offerings (they are called : banten saiban and canang sari) in places of worship such as merajan, listed and played the Puja Tri Sandya mantram and sacred songs through tape recorder (Informant, Wayan Wrnt., 03.03.19, I Made Sj., and $\mathrm{Ni}$ Ketut Sn., 27.03.19). In these ways, it is hoped that the religious atmosphere will be increasingly felt and imprinted in the person of the child which then manifests in the form of religious attitudes. As stated Muhaimin (2012: 298), that the creation of a religious atmosphere can first be done in a "top down" manner, then in subsequent periods strived to run "bottom up" and ultimately expected to become a tradition for the family. But the size of the influence depends on the factors that motivate children in living the religious atmosphere that is created. Because in essence the more religious the family atmosphere, the stronger the religious attitude of children (Jalaluddin, 2008: 295296).

Third, by internalizing religious values. Internalization of religious values is a process of fully incorporating religious values into the heart, so that the spirit and soul are based on religious teachings (Ancok, 2005: 13). Internalization of religious values in children in Hindu families in Taro Village is done by providing an understanding of religious values, so that they have a sradha and devotional attitude, and have a wise and wise nature (Ni Wayan Srtn., And Nyoman Rj., 12.04.19 ). This is possible because human beings are attached to two fundamental traits as stated in the Samkya doctrine in Bhagawadgita (XVI.3), that humans have the Daiwi Sampat nature ("deity") in accordance with dharma (virtue, truth); and Asuri Sampat (the nature of giant ) which contradicts dharma (Mantra, 1990: 30). Internalization of values in Hindu teenagers is done by the process of mutual learning. Planting and growing values can be done through a variety of methodical methods of education and teaching (Roibin, 2009: 75).

Fourth, by habituation (conditioning). Habituation is a certain behavior that is automatic without being planned in advance and acts just like that without thinking about it. Starting from the habituation of children (adolescents) can get used to obey the rules that apply in the community, such as respect for parents or elders, polite in speaking, greeting "Om Swastyastu", saying goodbye to the family if going to outside the home, praying before traveling, etc. (I Made $\mathrm{Sj}$., 27.03.19). Through habituation, there will be an awareness in every individual for religious culture (Roibin, 2009: 75). As Mahatma Gandhi said: "The method must be as good as the goal"; meaning that good goals must be achieved in good ways too (Wegig, 1989: 64).

Fifth, cooperation with formal and informal partners. In Taro Village there is a formal Pasraman managed by the 'Lembu Putih' Foundation owned by Pakraman Taro Kaja Village, and its management is responsible to the Regional Office of Religion in Gianyar Regency. The Pasraman in 2018 had 102 students, consisting of 52 kindergartens, 35 elementary schools, and 15 junior high schools. While in each banjar adat / pakraman village on the basis of community initiative and self-help, a nonformal pasraman was established named "Pasraman Budi Pekerti". The existence of this pasraman is considered to be very helpful for parents in order to form the religious attitudes of adolescents in Taro Village (I Ketut Rh., 28.04.19), and Made Sj., 09.05.19). Pasraman learning model emphasizes more on soft skills (practice) compared to general knowledge about Hindu religion that has been obtained in formal schools. Soft skills education is given, such as how to pronounce and tri-Sandya 
correctly, how to pray properly, making various types of canang, tipat, kuangen, ngangsah klangsah, klakat, sengkui, katik satay, practice and contests mekidung / correspondence, dharmagita contest, and the practice of yoga, as well as nguopin (the realization of the concept of local wisdom

Figure 1 Hindu Teenage of Taro

Village participates in the

competition to make klangsah and

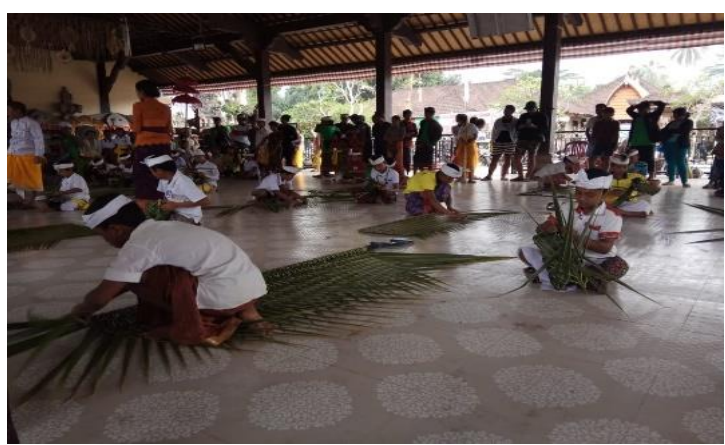

To form a healthy body and spirituality, teenagers are given the practice of yoga as shown in figure 03. According to yoga instructors at Pasraman Budi Peketi (I Wayan Wrnt., 27.04.19), the function of yoga is not only for that students are physically and mentally healthy, but by learning yoga students are expected to have compassion, patience, forgiveness, tolerance, self-control, as well as forming a religious attitude of children, because in learning yoga there are certain mantras or prayers that must be uttered by children.

Figure 3 Hindu Teenage of Taro Village follows yoga practice at Pasraman Budi Pekerti

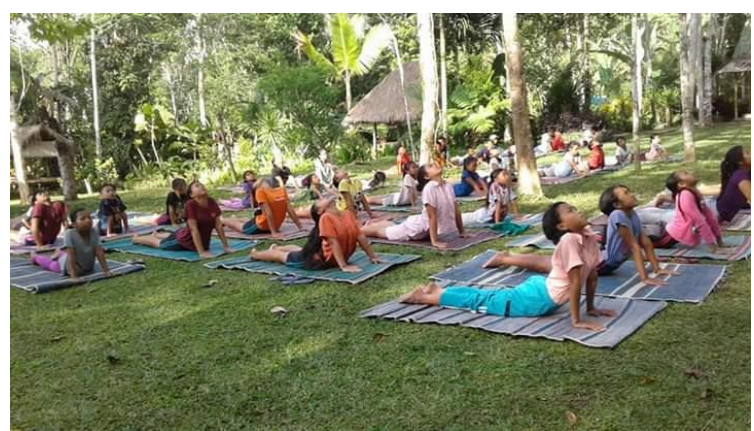

liking). Learning is centered on the Village Temple in the afternoon (at 15.00-18.00 p.m) every Wednesday and Sunday. The following are examples of pictures of children's activities at "Pasraman Budi Pekerti".

Figure 2 Hindu Teenage of Taro Village follows the Dharmagita competition

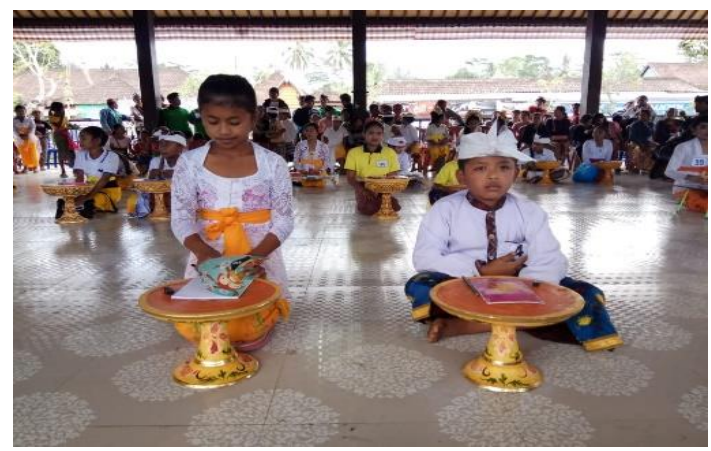

In order to strengthen Hindu customs and culture and religion, young people are given the opportunity to conduct nguopin / matulungan activities on Hindus families who have traditional ceremonial and religious activities as a realization of local wisdom. Through nguopin, children can practice their religious knowledge while at the same time shaping their religious attitudes, as shown in figure 04, teenagers happily go towards to their homes.

Figure 4 Hindu teenager goes to family's home who performed the Yadnya Dewa ceremony

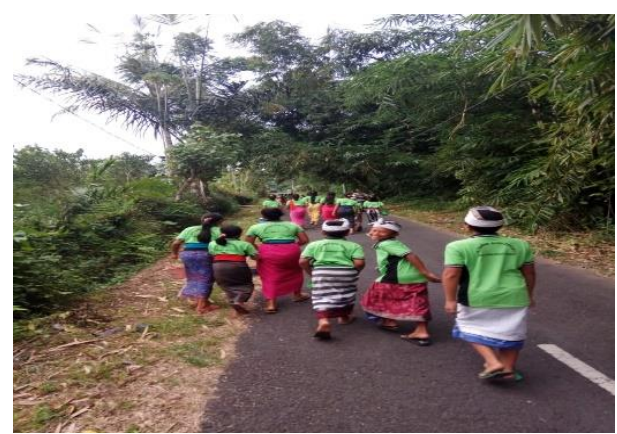




\section{Implications of the Formation of Religious Attitudes of Hindu Youth in Taro Village}

First, the implications for understanding religion. Understanding is a person's ability to interpret, translate or state something in his own way about knowledge that has been received (Muhaimin, 2012: 56). From the explanation above, the "understanding" in this study is the ability possessed by Hindu teenagers in Taro Village in interpreting or translating Hindu religious knowledge received from their environment. According to informants (Ni Made As., And I Made Jn., 27.04.19), along with the formation of religious attitudes, understanding and appreciation of adolescents about Hinduism also increased. According to informants, the understanding of adolescent religion is now intrinsic. They know Hindu teachings better, and on the other hand they want to study them deeper. The more the development of a child's age, his awareness to understand things in the abstract also increasingly developed, as stated Bridge \& Moore (2002: 67 ), that in adolescence the ability to think abstractly develops well.

Second, strengthening the faith / belief (sraddha and bhakti) in religion. The basis of belief is trust. Faith is an aspect of faith (sraddha) toward God and all that is revealed by Him. Faith is believing in the existence of God manifested by obedience in carrying out His commands and avoiding all His prohibitions (Zuriah, 2007: 83). Like Ni Nyoman Mrt's and Ketut Sj's opinion (03.03.19) 'if previously parents guided their children to pray and sometimes the children were not serious, but after their religious attitude was formed, the children became more solemn and earnestly prayed as if God was in front of them'. As stated by Petts (2015: 103), in the early days of life, religious beliefs are influenced by the socialization process of religious values from parents and family. As the child develops, his religious beliefs become stronger which starts from doubts and questions about concepts that have been accepted in childhood, including religious beliefs (Daradjat., 1991: 89).

Third, the implications for religious behavior. The growing religious attitude in children is manifested in daily patterns of religious behavior. The parents said, that the child's religious behavior or actions appear to be more mature and more stable, and the quality of his devotional service is also getting better, because religious actions are carried out with full awareness of the existence of God (Ida Sanghyang Widhi). Children's behavior becomes more polite, patient, and obedient to worship or fathering and pray to the temple (interviewed with $\mathrm{Ni}$ Nyoman Mt, and I Wayan Sd. 27.03.19). There are three theories that are usually used to analyze the formation of attitudes that have behavioral implications by Covey (in Ali, 2008: 43), namely: (1) Theory of Genetic Determinism, that individual attitudes are hereditary from their ancestors, (2) Theory of Determination Psychic that attitudes held by individuals are strongly influenced by parenting, and (3) Theory of Environmental Determinism, that the formation and development of individual attitudes are strongly influenced by environmental treatment of the individual. The three Covey theories and the informants' statements about the implications of religious attitudes on the religious behavior of Hindu teenagers in Taro Village are determined by heredity (genes), parenting patterns, and the environment.

\section{CONCLUCION}

The Hindu Community in Taro Village Tegalalang Gianyar considers that the formation of religious attitudes on Hindu youth is very important, because there are the Kahyangan Jagat Temple, Gunung Raung Temple, where Hindu youths are always involved in every ritual activity at those temples. Furthermore, Taro Village is also as a tourist destination with the interesting "White Ox" and beautiful natural panorama which is visited by many tourists. The tourists not only bring different cultures, they are also feared to bring values that are 
contrary to the values on local traditions or local wisdom of Taro Village. Some Christians also live mainly in Banjar Pakuseba, (partly in Taro) where there has been a conversion of religion from Hinduism to Christianity. In addition, the formation of religious attitudes is considered very important, because it can increase the religious knowledge of adolescents, can suppress the occurrence of religious fanaticism, form an attitude of tolerance with adherents of other religions, and make children of noble character.

The strategies used to shape the religious attitudes on Hindu youth include: (1) Giving examples and providing Models through persuasive approaches, such as observing worship, praying, behaving politely, and respecting others. (2) By creating religious atmosphere, such as always articulating the Puja Tri Sandya mantram, singing the hymns, and every day at least offering canang (offerings). (3) With the internalization of religious values, so as to penetrate into the hearts of children who will be reflected in the quality of their sraddha and devotion. (4) With habituation, such as being accustomed to saying Om Swastyastu, always respecting parents, polite in talking, praying and saying goodbye when leaving the house or traveling. (5) cooperation with formal and non-formal pasraman, especially in soft skills education, such as making canang, kuangen, tipat, ngangsah klangsah, klakat, sengkui, satik katik, mekidung, dharmagita, and yoga.

The formation of religious attitudes has implications for: (1) not only the understanding of adolescents about the teachings of Hinduism, but they also want to deepen the teachings of religion. (2) religious beliefs on youth are getting better with obedience in carrying out Hindu teachings. (3) The religious behavior of children growing up more mature, more stable in carrying out religious teachings, the quality of his devotional service is getting better, and running religious teachings with full awareness.

\section{REFERENCESS}

Ali, Muhammad. 2008. Perkembangan Peserta Didik. Bandung: PT. Remaja Rosdakarya.

Ancok, Djamaluddin. 2005. Religiusitas Sebagai Keberagaman. Yogyakarta: Pustaka Pelajar.

Bogdan, R. \& Taylor, S.J. 1992. Introduction to Qualitative Research Methods. New York:John Wiley and Sons.

Bridge, L.J., Moore, K.A. 2002. Religious and Spirituality in Childhood and Adolescence. Acssess from http://www.childtrends.org/files/200239 Religion Spirituality in Childhood Adolescence BridgeMoore012002.pdf. 2019, 5 April [Online].

Hasbullah. 2005. Dasar-Dasar Ilmu Pendidikan. Jakarta : PT Raja Grafindo Persada.

Jalaluddin. 1996. Psikologi Agama. Jakarta: PT. Raja Grafindo Perkasa.

Jalaluddin. 2008. Psikologi Agama Memahami Perilaku Keagamaan dengan Mengaplikasikan PrinsipPrinsip Psikologi. Jakarta: PT Raja Grafindo Persada.

Liliweri, Alo. 2003. Dasar-Dasar Komunikasi Antar Budaya. Yogyakarta: Pustaka Pelajar.

Mantra, 1990. Tata Susila Hindu. Jakarta: Hanuman Sakti.

Mercer, Jenny dan Debbie, Clayton. 2012. Psikologi Social. Jakarta: Penerbit Erlangga.

Moleong, L .J. 2014. Metodologi Penelitian Kualitatif. (Edisi revisi). Bandung: Remaja Rosdakarya.

Mujiati, Umi dan Triyanto, Andi. 2017. Pengaruh Lingkungan Keluarga dan Teman Sebaya Terhadap Perilaku Keberagamaan Siswa di SMA Muhammadiyah I Kota Magelang. Dalam Jurnal TARBIYATUNA, Vol.8, No. 1 Juni 2017.

Muhaimin. 2012. Studi Islam Dalam Ragam Dimensi dan Pendekatan. Jakarta: Kencana. 
Petts, R.J. 2015. "Parental Religiosity and Youth Religiosity: Variations by Family Structure". Sosiology of Religion. 76(1), 95-120.

Poerwandari, E， K. 2005. Pendekatan Kualitatif. Jakarta: Penerbit LPSP3.

Roibin. 2009. Relasi Agama \& Budaya Masyarakat Kontemporer. Malang: UIN Maliki Press.

Santrock. 2004. Perkembangan Masa Hidup. Jakarta: Erlangga.

Sastrapratedja (ed.). 1982. Manusia Multi Dimensional: Sebuah Renungan Filsafat. Jakarta: Gramedia.

Smith, Huston. 1995. Agama-agama Manusia. Terj. Safroedin Bahar. Jakarta: Yayasan Obor Indonesia.

Sukmadinata, Nana Syaodah. 2009. Metodologi Penelitian Pendidikan. Bandung: Remaja Rosdakarya.
Strauss, A., \& Corbin, J. 2015. Basics of Qualitative research: Techniques and Procedures for Developing Grounded Theory. USA: Sage Publications.

Thoha, Chabib, dkk. 1999. Metodologi Pembelajaran Agama. Yogyakarta: Pustaka Pelajar.

Thontowi, Ahmad. 2005. Hakekat Relegiusitas. Dalam http://sumsel. Kemenag.go.id/file/dokumen/hakekatr eligiusitas.pdf. Diakses pada 19 Pebruari 2019.

Wegig, R. Wahana. 1989. Dimensi Etis Ajaran Gandhi. Yogyakarta: Kanius.

Zuriah, Nurul. 2007. Pendidikan Moral dan Budi Pekerti dalam Perspektif PerubahanMengagas platform Pendidikan Budi Pekerti secara Kontekstual danFuturistik. Jakarta: PT Bumi Aksara. 